\title{
SOME REACTIONS TO A DRY-LAND TRAINING PROGRAMME FOR DINGHY SAILORS
}

\author{
G. WRIGHT, J. CLARKE, V. NIINIMAA \& R. J. SHEPHARD
}

Dept. of Environmental Health, School of Hygiene, University of Toronto

\begin{abstract}
A dry-land winter training programme for dinghy-sailors is described. Individual elements include circuit training, specific exercises for muscle strength and endurance, and distance running. Ten international-class sailors followed a progressive regimen of this type for 14 weeks after completion of the 1973 season. Excess weight and skinfold thicknesses were reduced, while muscle strength, endurance and anaerobic capacity increased. Aerobic power remained substantially unchanged, although a smaller oxygen debt was incurred in reaching maximum effort. Team members were enthusiastic about the benefits gained from the training, commenting on their greater tolerance of the hiking position and all proposed to continue or to increase their efforts during subsequent winters. Racing results during 1974 were also an improvement on the 1973 record. However, it was difficult to link physiological gains to improvements in the relative rankings of individual competitors under either light or high wind conditions; the main factor changing relative standings seems to have been the additional year of competitive experience in younger team members.
\end{abstract}

\section{INTRODUCTION}

In a previous report (6), we have drawn attention to the marked bearing that physiological attributes muscle strength, muscle endurance, aerobic power, anaerobic capacity and balance - have upon the outcome of dinghy-sailing contests, particularly when the wind-velocity is high. During the sailing season, crewmembers develop both the necessary physiological characteristics and also competitive skills through long hours of sailing. However, in continental climates such as that of Toronto, the sailing season is short, and accordingly we have explored the possibility of sustaining and/or developing fitness through an appropriately designed dry-land training programme. The present paper discussed both team attitudes and responses to this programme.

\section{METHODS}

Subjects and experimental plan.

The subjects were ten international-class dinghy sailors, all members of the Ontario division of Sail Canada. Details of physical characteristics will be found in another report published elsewhere (6). Initial physiological observations were made at the immediate end of the sailing season, and measurements were repeated after 14 weeks of strenuous and progressive dry-land training. Data collected included standard anthropometric observations, skinfold thicknesses, muscle strength (handgrip, forearm flexion and extension, knee extension), muscle endurance $(50 \%$ and $75 \%$ of maximum voluntary quadriceps contraction), balance (stork-stand and stabilometer scores), aerobic power, simulated "hiking" (with measurement of heart rate, blood pressure, blood sugar and serum bicarbonate) and anaerobic capacity (endurance of treadmill run at 6 m.p.h., 20\% slope). Tests generally followed standard I.B.P. methodology
(10) and have been described in the previously mentioned report (6).

\section{Training plan.}

The training programme was followed for a total of 14 weeks, and called for a minimum attendance of four sessions per week. During this period, each of the sailors kept a careful record of the training actually accomplished. The average attendance at classes $4.0 \pm 1.5$ days per week, with individual maxima of $5.1 \pm 1.5$ and minima of $2.0 \pm 1.7$ sessions per week. The average time devoted per session was $47.0 \pm 16.0 \mathrm{~min}$, with individual maxima of $62.0 \pm 26.5 \mathrm{~min}$ and individual minima of $35.5 \pm 22.0 \mathrm{~min}$.

The programme commenced with circuit training (5) at a level appropriate to the individual's initial fitness. On reaching level 4 (Blue 2), circuit training was continued twice per week, and two weekly sessions of weight-training were gradually phased-in with increasing loads and repetitions. Weight exercises included:-

(i) Sit-ups from downward sloping board with 15 pound dumb-bell behind head ( 8 increasing to 15 repetitions per circuit)

(ii) Leg-press (subject laying on his back and elevating weight of $200-300$ pounds by knee extension, 15 repetitions per circuit)

(iii) Pulley work (arm movements to maximum available pulley loading, using both arms simultaneously, 50-100 repetitions per circuit of (a) raising arms above head in sagittal plane, (b) flexion of arms towards chest and (c) extension of arms in frontal plane

Key words:

Circuit Training, Strength Training, Endurance Training, Dinghy Sailing, Winter Training 
(iv) Sit-ups from "hiking" position with 15 pound dumb-bell behind head ( 30 increasing to 50 repetitions)

(v) Quadriceps exerciser-standard apparatus, with loading increasing from 70 to 100 pounds, each leg being exercised separately (10 repetitions per circuit)

(vi) Clean and press - standard technique, starting at 90 pounds and progressing to 120 pounds (10 repetitions per circuit).

On weight-training days, each circuit of 6 items was repeated three times with a two minute rest interval between each circuit. Towards the end of the first month (depending on the progress of the subject) one of the strength sessions was replaced by a muscle endurance session where each item in the strength circuit was repeated three times before moving on to the next station.

During the second month, one day was devoted to standard circuit training (level 5) two days to a muscle endurance session (as above), and one day to a strength session (as above).

In the third month, the programme was supplemented further by $2-4$ miles of running at the best possible speed once or twice per week.

\section{RESULTS}

\section{Subjective reactions to training.}

Subjective reactions to the training programme were assessed by means of a multiple-choice questionnaire. Reasons cited for interest in the programme included a desire to improve general fitness (6), strength (3), endurance (7) and competitive performance (4), the hope of losing weight (1), the receipt of advice on proper conditioning techniques (1) and the general enjoyment and interest gained from physical activity (3). Nine of the ten subjects thought that they had benefitted "a great deal" from the winter training, and one thought he had benefitted "somewhat". Gains of physical abllity to sail, as anticipated, were greatest when the wind was strong:

$\begin{array}{llllll}\text { Wind } & \begin{array}{l}\text { Much } \\ \text { better }\end{array} & \text { Better } & \begin{array}{l}\text { No } \\ \text { change }\end{array} & \text { Worse } & \begin{array}{l}\text { Much } \\ \text { worse }\end{array} \\ \text { Light } & - & 4 & 6 & - & - \\ \text { Moderate } & 2 & 7 & 1 & - & - \\ \text { High } & 4 & 6 & - & - & -\end{array}$

Gains of tactical ability (e.g. choice of currents) were also greatest when the wind was strong:

$\begin{array}{llllll}\text { Wind } & \begin{array}{l}\text { Much } \\ \text { better }\end{array} & \text { Better } & \begin{array}{l}\text { No } \\ \text { change }\end{array} & \text { Worse } & \text { Much } \\ \text { Light } & 1 & 2 & 7 & - & - \\ \text { Moderate } & 2 & 3 & 5 & - & - \\ \text { High } & 2 & 4 & 4 & - & -\end{array}$

With regard to perceived changes of fitness, the main gain was in cardio-vascular endurance 16 "much better," 4 "better"). However, there were also subjective gains of muscular endurance ( 3 "much better," 6 "better", 1 "no change") and muscular strength (1 "much better," 7 "better," 2 "no change").

In view of the nature of the programme, we were quite surprised that most subjects rated their chosen intensity of training hardest for the cardiovascular component:

Vory hard modium fairly light
hard

$\begin{array}{llllll}\begin{array}{l}\text { Muscle } \\ \text { strength }\end{array} & 1 & 2 & 5 & 1 & 1 \\ \begin{array}{l}\text { Muscle } \\ \text { endurance }\end{array} & 1 & 3 & 6 & - & - \\ \begin{array}{l}\text { Cardiovasc. } \\ \text { endurance }\end{array} & 5 & 3 & 2 & - & -\end{array}$

Despite these assessments, four subjects augmented their prescription "a little" and five by " a moderate amount" of additional voluntary activity. Interest in the programme was indicated by the fact that all of the team continued the gymnasium programme after the start of the new sailing season (although in eight of the ten the intensity of training was reduced). All planned to exercise in the gymnasium in subsequent winters, eight of them at a more intense level. Five expressed a preference for more strength training, four for more cardiovascular training, and two for more muscular endurance work. One planned to reduce strength training, and one to reduce cardiovascular training.

\section{Changes in physical characteristics.}

Team members showed a highly significant reduction in body weight over the course of dry-land training; this was due largely to $11.6 \mathrm{~kg}$ loss of weight by one individual who initially carried $18.7 \mathrm{~kg}$ excess weight. At the same time, there was a significant increase of quadriceps girth (Table I). All except one of the eight skinfold readings also showed a decrease, the final average of $10.8 \mathrm{~mm}$ being much closer to the previously reported normal value of $10.4 \mathrm{~mm}$ for young Toronto men (8). Other anthropometric variables, including shoulder and hip widths and the height of the centre of gravity showed no significant change over the training programme. 


\section{TABLE I}

Physical characteristics of sailors before and after training.

\begin{tabular}{|c|c|c|c|}
\hline Variable & $\begin{array}{l}\text { Initial } \\
\text { value }\end{array}$ & $\begin{array}{l}\text { Final } \\
\text { value }\end{array}$ & $\begin{array}{l}\text { Change with } \\
\text { training }\end{array}$ \\
\hline Weight (kg) & 84.4 & 82.5 & $\begin{array}{l}-1.9 \\
\pm 0.4 * * *\end{array}$ \\
\hline $\begin{array}{l}\text { Estimated } \% \\
\text { body fat }\end{array}$ & 19.9 & 19.7 & $\begin{array}{l}-0.2 \\
\pm 3.1\end{array}$ \\
\hline $\begin{array}{l}\text { Quadriceps girth } \\
(\mathrm{cm})\end{array}$ & 47.0 & 48.5 & $\begin{array}{l}+1.5 \\
\pm 2.0^{*}\end{array}$ \\
\hline \multicolumn{4}{|l|}{$\begin{array}{l}\text { Skinfold readings } \\
(\mathrm{mm})\end{array}$} \\
\hline 1. Triceps & 11.8 & 10.4 & $\begin{array}{l}-1.4 \\
\pm 2.9\end{array}$ \\
\hline 2. Subscapular & 15.0 & 12.7 & $\begin{array}{l}-2.3 \\
\pm 6.0\end{array}$ \\
\hline 3. Suprailiac & 15.4 & 18.2 & $\begin{array}{l}+2.5 \\
\pm 6.2\end{array}$ \\
\hline 4. chin & 7.9 & 6.1 & $\begin{array}{l}-1.8 \\
\pm 1.4^{* *}\end{array}$ \\
\hline 5. Medial knee & 13.6 & 11.2 & $\begin{array}{l}-2.4 \\
\pm 4.3\end{array}$ \\
\hline 6. Chest & 14.0 & 9.3 & $\begin{array}{l}-4.7 \\
\pm 7.7\end{array}$ \\
\hline 7. Abdomen & 19.0 & 11.8 & $\begin{array}{l}-7.2 \\
\pm 5.0^{* *}\end{array}$ \\
\hline 8. Suprapubic & 10.6 & 6.4 & $\begin{array}{l}-4.2 \\
\pm 4.5^{*}\end{array}$ \\
\hline$\sum 1-3$ & 14.1 & 13.8 & $\begin{array}{l}-0.3 \\
\pm 4.0\end{array}$ \\
\hline$\sum 1-8$ & 13.4 & 10.8 & $\begin{array}{l}-2.6 \\
\pm 3.4\end{array}$ \\
\hline${ }^{*} P<0.05 \quad * * F$ & $1 \quad * * *$ & .001 & \\
\hline
\end{tabular}

3. Changes in strength, endurance, and balance.

Three of the four measures of muscle strength showed an increase over the training programme, the gain being statistically significant in one measurement, and almost significant in a second. The exception was the quadriceps, where (probably on account of difficulties in hip immobolizationi scores were very variable and an insignificant decrease of strength occurred. (Table II)

The endurance of the quadriceps muscle was substantially increased; the fact that a large response occurred at $50 \%$ of maximum voluntary contraction, with little change at $75 \%$ is in keeping with the known interaction of muscle contraction and blood flow (7) and supports a physiological rather than a psychological basis for the gain of endurance. The terminal heart rate during the endurance efforts was identical before and after training, and there was an insignificant increment of the final systolic blood pressure (to $207 \mathrm{mmHg}$ in both conditions).
TABLE II

Muscle strength, muscle endurance and balance before and after training. Mean \pm S.D.

\begin{tabular}{|c|c|c|c|}
\hline Variable & $\begin{array}{l}\text { Initial } \\
\text { value }\end{array}$ & $\begin{array}{l}\text { Final } \\
\text { value }\end{array}$ & $\begin{array}{l}\text { Change with } \\
\text { training }\end{array}$ \\
\hline \multicolumn{4}{|l|}{ Strength } \\
\hline Handgrip force & 62.2 & 63.4 & +1.2 \\
\hline $\begin{array}{l}(R+L, k g) \\
\quad 2\end{array}$ & & & \pm 3.6 \\
\hline $\begin{array}{l}\text { Forearm flexion } \\
\text { force }(\mathrm{kg})\end{array}$ & 46.1 & 50.2 & $\begin{array}{l}+4.1 \\
\pm 6.5(*)\end{array}$ \\
\hline $\begin{array}{l}\text { Forearm extension } \\
\text { force }(\mathrm{kg})\end{array}$ & 38.1 & 43.1 & $\begin{array}{l}+4.8 \\
\pm 4.7^{*}(*)\end{array}$ \\
\hline $\begin{array}{l}\text { Quadriceps extension } \\
\text { force }(\mathrm{kg})\end{array}$ & 106.4 & 101.6 & $\begin{array}{l}-4.8 \\
\pm 20.7\end{array}$ \\
\hline \multicolumn{4}{|l|}{ Endurance } \\
\hline $\begin{array}{l}\text { Quadriceps, } 50 \% \text { max. } \\
\text { vol. contraction } \\
\text { (sec) }\end{array}$ & 83.7 & 117.3 & $\begin{array}{l}+33.6 \\
\pm 30.9^{* *}\end{array}$ \\
\hline $\begin{array}{l}75 \% \text { max. vol. } \\
\text { contraction (sec) }\end{array}$ & 38.6 & 45.8 & $\begin{array}{l}+7.2 \\
\pm 14.1\end{array}$ \\
\hline \multicolumn{4}{|l|}{ Balance } \\
\hline \multicolumn{4}{|l|}{ Stork stand } \\
\hline (right, sec) & 30.9 & 36.9 & $\begin{array}{l}+6.0 \\
\pm 25.2\end{array}$ \\
\hline (left, sec) & 35.4 & 35.6 & $\begin{array}{l}+0.2 \\
\pm 13.6\end{array}$ \\
\hline Stabilometer (sec) & 123.4 & 133.7 & $\begin{array}{l}+10.3 \\
\pm 9.7^{* *}\end{array}$ \\
\hline
\end{tabular}

*P<0.05 ** $P<0.01$

The balance scores showed small gains, significant for the stabilometer. However, the training programme did not include specific balance work, and this gain may thus represent no more than learning the test procedure.

\section{Aerobic power.}

On average, our subjects maintained a remarkably stable level of aerobic power over the winter programme (Table III). Since the majority of subjects finished their sailing season with a high $\mathrm{VO}_{2}(\max )$ and the dryland programme incorporated only 1-2 days of running per week into its final phase, it is hardly surprising that in the majority of sailors aerobic power was sustained rather than improved. Nevertheless, four of the team members showed some improvement, and the subject with the lowest initial $\mathrm{VO}_{2}(\max )$ registered a gain of $10.3 \%$. Further, although running speed was kept constant (6 $\mathrm{mph}$ ), all subjects were capable of performing more work at the final test, the average terminal slope increasing from 8.8 to $10.9 \%$, and the total test duration rising from 11.6 to $14.2 \mathrm{~min}$. 
TABLE III

Aerobic power and related variables. Measurements made before and after training. Mean \pm S.D.

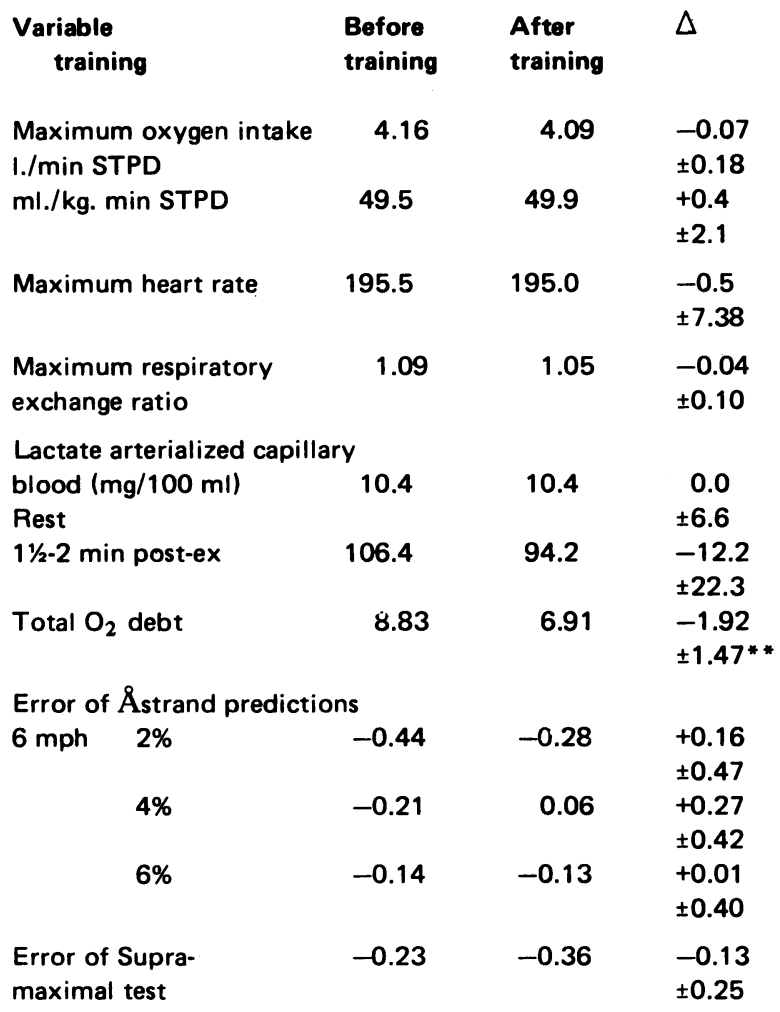

** $P<0.01$

Despite the increase of performed work, the terminal heart rate was very consistent; perhaps because of the gains in muscle strength and endurance and associated enzyme development, subjects were able to reach this heart rate and oxygen consumption with a smaller accumulated blood lactate, oxygen debt and respiratory gas exchange ratio. Changes in oxygen debt reflected the lactate component $(\Delta-1.92 \pm 1.47$ I.) with no change in the alactate debt $(\Delta-0.03 \pm 0.89$ l. $)$.

The systematic error for Åstrand predictions of aerobic power tended to diminish with training, although differences between initial and final errors were not statistically significant.

\section{Anaerobic capacity.}

The endurance time for supramaximal effort (uphill treadmill running, $6 \mathrm{mph}$ at $20 \%$ slope) increased insignificantly (from 65.1 to $94.0 \mathrm{sec}$ ) with training.

\section{Biochemical responses to simulated hiking.}

There was a statistically insignificant suggestion that resting blood glucose and serum bicarbonate were increased with training; however, biochemical responses to five minutes of simulated "hiking" remained unchanged.

\section{Captain's ratings.}

The captain's rankings of sailing ability prior to training and after the new sailing season are summarized in Table IV. Under light wind conditions, subjects $R, K j$ and $K h$ showed a gain of ranking of 2 or more places, while $C$, $\mathrm{Bb}$ and $\mathrm{K}$ showed a deterioration of standing. Under high wind conditions, $\mathrm{Kj}, \mathrm{Kh}$ and $\mathrm{E}$ showed gains and $\mathrm{Bb}, \mathrm{Br}, \mathrm{C}$ and $\mathrm{K}$ loss of standing. The physiological basis for these changes of ranking can be brought out by comparing objective performance scores. Under light conditions, the gains cannot be ascribed to an increment of resting blood glucose (Table V). The three sailors who improved had relatively little initial experience of competition (2-5 years), while two of the three who lost standing had been sailing for many years, and one (c) admitted that his interest in the sport was now waning; we would thus conclude that the additional year of experience largely explained the gains realised by the more junior team members. Under high wind conditions, the most obvious casualty was subject $\mathrm{Br}$. He lost 11.6 $\mathrm{kg}$ weight over the training programme, falling from an excess weight of $18.7 \mathrm{~kg}$ to $7.1 \mathrm{~kg}$. Although his average skinfold readings decreased from 18.0 to $10.1 \mathrm{~mm}$, there was also a decrease in maximum force in three of the four muscle groups tested, the largest change being in the quadriceps (extension force $150 \rightarrow 93 \mathrm{~kg}$ ); presumably, the drastic loss of body weight in his case was accompanied by some loss of muscle protein. He also suffered some loss of aerobic power $(0.33 \mathrm{I} . / \mathrm{min})$ during the dryland training programme. Two of the other three sailors who lost relative ranking initially had the highest physiological scores ( $\mathrm{Bb}$ and $\mathrm{C}$ ) and for this reason had relatively little scope to improve in physiological status over the course of training. Two of the three who gained in ranking were relatively inexperienced ( $\mathrm{Kj}$ and $\mathrm{Kh})$. In physiological terms, they showed little change of aerobic power, small gains of quadriceps extension force, larger improvements in anaerobic treadmill performance (average for 3 subjects 35 sec gain, compared with $26 \mathrm{sec}$ for remainder of group) but relatively small changes in tolerance of sustained quadriceps contraction (average $18 \mathrm{sec}$, compared with $50 \mathrm{sec}$ for the remainder of the group). The only important difference between international and regional standings was under high wind conditions; the very experienced $\mathrm{C}$ moved from fifth to second rank under the pressures of an international contest. 
TABLE IV

Captain's ranking of sailing performance under various wind conditions (initial rankings after 1973 season, final rankings after 1974 sason, with assessment of performance in international and regional competitions, 1974.

Initial Captain's

Light wind High wind Light wind High wind

E Bb

C R

$\mathrm{Bb} \quad \mathrm{Br}$

$R \quad C$

Kj $\quad K j$

$\mathrm{Br} \quad \mathrm{K}$

K $\quad K h$

Kh T

$T \quad E$

* gain of standing tloss of standing
Regional comp.

Light wind High wind

E

E

C

$\mathrm{Kj}$

$\mathrm{Kh}$

$M$

$\mathrm{Br}$

$\mathrm{Bb}$

$K$

$T$
R

$\mathrm{Kj}$

$\mathrm{Kh}$

$\mathrm{Bb}$

$\mathrm{Br}$

E

M

K

$T$
Final Rating of Captain

$\begin{array}{lll}\text { Light } & \text { Shifting } & \text { Steady } \\ \mathrm{E} & \mathrm{C} & \mathrm{R} \\ \mathrm{R}^{*} & \mathrm{E} & \mathrm{Br} \\ \mathrm{Kj}^{*} & \mathrm{R} & \mathrm{C} \\ \mathrm{Kh}^{*} & \mathrm{Bb} & \mathrm{E} \\ \mathrm{Ct} & \mathrm{Kj} & \mathrm{Bb} \\ \mathrm{Bbt} & \mathrm{Kh} & \mathrm{Kj} \\ \mathrm{Br} & \mathrm{M} & \mathrm{Kh} \\ \mathrm{M} & \mathrm{Br} & \mathrm{M} \\ \mathrm{T} & \mathrm{T} & \mathrm{T} \\ \mathrm{K} \dagger & \mathrm{K} & \mathrm{K}\end{array}$

High wind

R

$\mathrm{Ki}^{*}$

$\mathrm{Kh}^{*}$

$\mathrm{Bbt}$

Brt

$\mathrm{Ct}$

$\mathrm{E}^{*}$

$T$

$\mathrm{K} \dagger$

\section{TABLE V}

Subjects listed according to captain's initial ranking for light wind conditions showing objective (non-parametric) performance scores (6) before and after training.

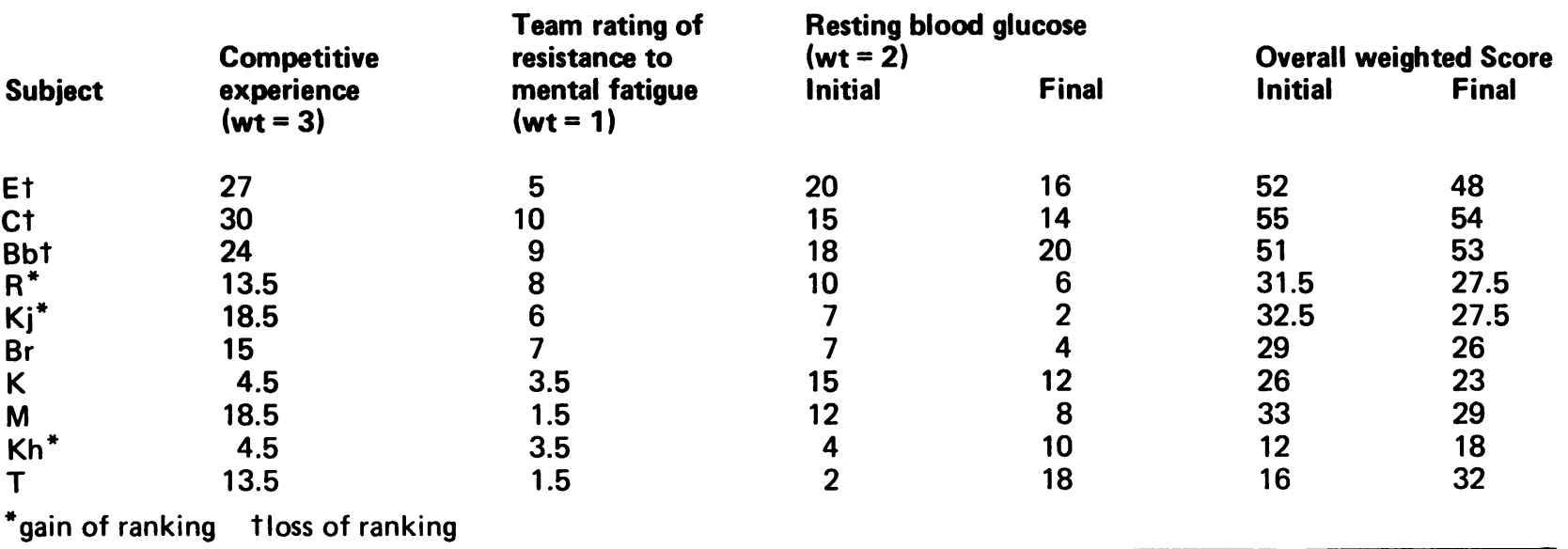

TABLE VI

Subjects listed according to captain's initial ranking for high wind conditions, showing objective (non-parametric) performance scores (6) before and after training.

\begin{tabular}{|c|c|c|c|c|c|c|}
\hline \multirow[b]{2}{*}{ Subject } & \multicolumn{2}{|c|}{$\begin{array}{l}\text { Years of } \\
\text { experience }\end{array}$} & \multicolumn{2}{|c|}{$\begin{array}{l}\text { Quadriceps Ext. } \\
\text { force (wt = 2) }\end{array}$} & \multicolumn{2}{|c|}{$\begin{array}{l}\text { Aerobic power } \\
(1 . / \mathrm{min}) \mathrm{wt}=2\end{array}$} \\
\hline & Total & Comp. & Initial & Final & Initial & Final \\
\hline Bbt & 18 & 10 & 18 & 20 & 12 & 12 \\
\hline$R$ & 15 & 4 & 6 & 13 & 18 & 18 \\
\hline $\mathrm{Brt}$ & 4 & 4 & 20 & 8 & 20 & 16 \\
\hline $\mathrm{C}+$ & 24 & 24 & 16 & 16 & 16 & 20 \\
\hline $\mathrm{Kj}^{*}$ & 15 & 5 & 12 & 13 & 14 & 14 \\
\hline $\mathrm{Kt}$ & 6 & 2 & 14 & 18 & 10 & 10 \\
\hline $\mathrm{Kh}^{*}$ & 12 & 2 & 2 & 3 & 8 & 8 \\
\hline M & 12 & 5 & 10 & 8 & 6 & 4 \\
\hline$T$ & 14 & 4 & 8 & 10 & 4 & 6 \\
\hline$E^{*}$ & 29 & 22 & 4 & 3 & 2 & 2 \\
\hline
\end{tabular}

\begin{tabular}{|c|c|c|}
\hline \multirow{2}{*}{$\begin{array}{l}\text { Resistance } \\
\text { to fatigue } \\
\text { (wt = 2) } \\
\text { Initial }\end{array}$} & \multicolumn{2}{|c|}{$\begin{array}{l}\text { Anaerobic end } \\
(w t=1)\end{array}$} \\
\hline & Initial & Final \\
\hline 18 & 4 & 5 \\
\hline 16 & 7 & 4 \\
\hline 14 & 9 & 9 \\
\hline 20 & 8 & 8 \\
\hline 12 & 10 & 10 \\
\hline 7 & 6 & 6 \\
\hline 7 & 5 & 7 \\
\hline 3 & 3 & 3 \\
\hline 3 & 2 & 1 \\
\hline 10 & $\overline{1}$ & 2 \\
\hline
\end{tabular}

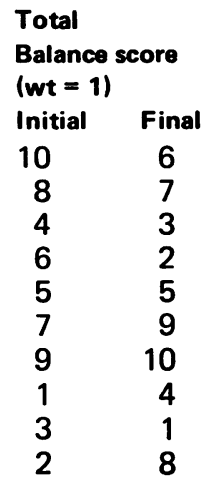

Overall score

Initial Final No

626010

55

67

66

53

44

31

23

20

19

* gain of standing tloss of standing 


\section{DISCUSSION}

\section{Effectiveness of dryland training.}

In addition to the enthusiastic response of the individual crew-members to the dryland training programme, the group made substantial gains in their overall competitive position from the 1973 to the 1974 season, the 1974 results including second place in the Finn championships of North America (R), second place in the Canadian Flying Dutchman championships and third place in the North American Flying Dutchman championships (Kj and $\mathrm{Kh}$ ), first place in the Canadian youth championships (M) and firsts in other events by the remaining participants.

While increasing experience and other non-physiological factors could have contributed to these successes, it seems significant that at the end of the dryland training programme 8 of the 10 team members had improved their quadriceps endurance and thus presumably their ability to hike. It is also noteworthy that the best balance scores were attained by the Flying Dutchman and 470 sailors, while the highest values for absolute aerobic power (maximum oxygen intake not adjusted for body weight) were seen in four of the five Finn sailors.

\section{Pattern of training response.}

There was a marked discrepancy between subjective perception of training (mainly cardiovascular endurance work, with substantial gains of cardiovascular fitness) and the physiological response (maintenance of aerobic status, with reduction of body fat, gains of strength, muscle endurance and anaerobic capacity). While the observed physiological changes could contribute to the improved standing of all team members, it is more difficult to explain changes in their relative status in physiological terms. Under light wind conditions, the main factor seems to have been the increasing experience of junior team members and some waning of enthusiasm by older members of the group, and even under high wind conditions the only area of training where the upwardly mobile team members made larger gains than their fellow members was in the development of anaerobic capacity.

The response seen in subject $\mathrm{Br}$ emphasizes the difficulty in producing weight loss without loss of lean tissue; despite participation in the strenuous muscle training programme as outlined, and a weight loss $<1 \mathrm{~kg}$ per week, he apparently suffered some loss of lean tissue as shown by the decrease of both muscle strength and aerobic power.

The glycogen-sparing function of strength and endurance training is well illustrated by average results for the group. After the dryland training programme, subjects were able to reach the same heart rate and approximately the same maximum oxygen intake while building up a much smaller oxygen debt. Possible mechanisms for the reduction of anaerobic work include (a) a faster on-transient of blood flow to the active muscles, (b) more ready perfusion of the muscles because they are contracting at a smaller percentage of their maximum force $(3,4)$, and (c) facilitation of aerobic metabolism by increase of muscle myoglobin and enzyme concentrations. The strengthening of the muscles supports the second mechanism, and there is also good reason to suppose that enzyme concentrations were increased by the 14 weeks of vigorous muscle training (1.2).

As in a number of previous experiments, the discrepancy between directly-measured and predicted maximum oxygen intake values decreased over the course of training. This is probably due at least in part to a progressive habituation of the subjects to the test laboratory (9).

\section{ACKNOWLEDGEMENT}

This work was supported in part by a research grant from Sail Canada. We are indebted to Dr. J. Clapp for the estimations of blood glucose.

\section{REFERENCES}

1. Gollnick, P. D. \& Hermansen, L. 1973. Biochemical adaptations to exercise: anaerobic metabolism. Exercise and Sports Sciences Rev. 1, 1-43.

2. Holloszy, J. O. 1973. Biochemical adaptations to exercise: aerobic metablism. Exercise and Sports Sciences Rev. 1, 46-71.

3. Kay, C. \& Shephard, R. J. 1969. On muscle strength and the threshold of anaerobic work. Int.Z.angew.Physiol. 27 , $311-328,1969$.

4. Lind, A. R. \& McNicol, G. W. (1967). Muscular factors which determine the cardiovascular responses to sustained and rythmic exercise. Can.Med.Ass.J. 96, 706-713. 
5. Morgan, R. E. \& Adamson, G. T. 1965. Circuit-training, 2nd Edition. London: G. Bell.

6. Niinimaa, V., Wright, G., Shephard, R. J. \& Clarke, J. 1975. Characteristics of the successful dinghy sailor. In preparation.

7. Royce, J. 1958. Isometric fatigue curves in human muscle with normal and occluded circulation. Res. Quart. 29, 204-212.

8. Shephard, R. J. 1969. Learning, habituation and training. Int.Z.angew.Physiol. 28, 38-48.

9. Shephard, R. J. 1969. Endurance Fitness. Toronto: University of Toronto Press.

10. Weiner, J. S. \& Lourie, J. A. 1969. Human Biology. A guide to field methods. Oxford, U.K.: Blackwell Scientific Publications. 